\title{
Local Mineral Clays, Characterization and Application in Petroleum Refining
}

\author{
R. A. Buker \& $\quad$ M. Z. Hamoodat \\ Department of Chemistry / College Of Education \\ University of Mosul
}

\section{Received \\ $11 / 05 / 2010$}

\author{
Accepted \\ 05 / 01 / 2011
}

الملخص:

تتضمن الدراسة تحضير ودراسة حفاز طيني معدني من معادن طينية محلية أخذت من

مناطق قريبة دن مدينة الموصل /العراق • وقد استخدمت هذه الحفازات في فصل وتتقية النفوط

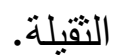

تم دراسة الصفات الفيزبائية للنماذج قيد الدرس فضلاً عن قابلية ذوبانها في عدة

حوامض، كما تم دراسة التكوين الكيميائي والتركيب البلوري للمعادن الطينية المحلية والمحضرة

من خلال استخدام طرق التحليل الكيميائية الكلاسيكية وتقنيات فلورة وحيود الأشعة السينية والتحاليل الحرارية فضلاً عن أطياف الأشعة تحت الحمراء.

سلطت نتائج الدراسة الضوء على المعدن الطيني المحضر كونه حفاز كفوء في فصل

مشتقات نفط القيارة التقيل إلى مكونات ابسط نم التعرف عليها وتشخيصها باستخدام تقنية طيف الأشعة تحت الحمراء.

\begin{abstract}
The study includes preparation and characterization of Mineral clay catalysts from local and natural mineral clays, which have been applied in purification and fractionation of heavy crude oils.

The studied samples were collected from area around Mosul city /Iraq. Physical properties were investigated to characterize the clay samples in addition to their solubility in many acids. Meanwhile, classical chemical analysis and X-Ray fluorescence were applied to determine their chemical composition.

Moreover, X-Ray diffraction, thermal analysis, and infrared spectroscopy have been used to study their structural properties. Such
\end{abstract}


investigations spot the light on the prepared sample to be active and selective in term of the adsorption chromatography. Qaiyarah heavy crude oil was fractionated into its simple and useful components which have been characterized via infrared spectroscopy.

\section{Introduction :}

Mineral clays are among several naturally occurring materials used in adsorption chromatography for the separation of complex mixtures of substances like heavy crude oils, into their simple and useful components $^{(1-3)}$. The idea of adsorption and fractionation might be explained in term of the structure of the catalyst materials. They are porous in nature so they can hold water molecules as adsorbed, interlayer or lattice-OH water. The adsorbed water at relatively low temperature is driven off by heating to about $450^{\circ} \mathrm{C}{ }^{(4)}$. Organic molecules are dipoles and act in the same manner as water molecules when they are in contact with the catalysts ${ }^{(5)}$.

In general clays contain one or more of clay mineral components, in addition to relative amounts of non-clay mineral such as quartz, calcite, dolomite, gypsum, pyrite......etc ${ }^{(6)}$. Treatment of such materials was constructed by several diluted and concentrated acids and hydroxides to obtain good adsorbent catalysts ${ }^{(7)}$. It is obviously noted that almost carbonate and sulphate compounds, which are non-clay minerals, eliminated during the treatment leading to the formation of clay minerals rich adsorption catalysts.

It is well known that Hammam Al-Alil bitumen and Qaiyarah heavy crude oil fields which are located north of Iraq have not been used till recently ${ }^{(8-9)}$. Such materials are important in the energy sources, and the future promises further substantial increase in demand. Accordingly, some workers investigated the evaluation and fractionation of such crude oils to light fuels and petrochemical ${ }^{(10-12)}$. In general, zeolite, clay, alumina and silica gel were used as adsorbents to perform the above processes. However, clay materials seemed to be the most widely used adsorbents in this field since they are available in high purity with moderate cost, can be made with a range of physical properties, and they are chemically inert. Natural Iraqi Fuller's Earth ${ }^{(13)}$ were employed and investigated in fractionation processes as adsorbent materials by many workers $^{(7,14)}$.

In order to continue researching for our raw materials and investigating their benefit uses, the present study is undertaken to extend the investigation via the treatment of clay mineral by multi acids. The prepared catalyst is to be characterized and employed in adsorption chromatography. 


\section{Experimental}

\section{A- Sampling methods :}

The samples used in this research were obtained from area around Mosul city/Iraq. They were pale green in color has (120-150 mesh) chromatographic grade, bearing suitable amounts of clay minerals like feldspar, caolinite montmorolinite and playgroskite as reported recently ${ }^{(7)}$. Such samples were used as starting materials for preparation of activated natural and treated clay samples. The latter was obtained by refluxing a known weight of natural clay with a suitable amount of $25 \%$ hydrochloric acid for two hours ${ }^{(15)}$. The result material after filtration and washing by distilled water was dried at $115^{\circ} \mathrm{C}$. The differences in weights before and after the treatment was recorded for this sample which was then used for further treatment processes. $25 \%$ in concentration of $\mathrm{HNO}_{3}, \mathrm{H}_{2} \mathrm{SO}_{4}$, $\mathrm{H}_{3} \mathrm{PO}_{4}$ and $\mathrm{CH}_{3} \mathrm{COOH}$ were used progressively and in the same procedure mentioned above in case of $25 \% \mathrm{HCl}$ to obtain the treated clay sample.

\section{B- Chemical and physical properties:}

Chemical compositions of the natural and prepared clay samples were determined via several chemical and physical processes started by sodium fusion technique ${ }^{(16)}$, which followed by dissolving the content in $6 \mathrm{M} \mathrm{HCl}$ in order to prepare stock solution for a full instrumental and classical chemical analysis. Such analysis was reinforced by X-Ray fluorescence method ${ }^{(17)}$. Moreover, physicochemical properties also were measured like $\mathrm{PH}$, density, porosity and specific surface area ${ }^{(15)}$.

\section{C- Thermal analysis :}

Thermogravimetric(TG) and differential thermal analysis (DTA) were obtained simultaneously on a Stan Redcroft STA-780 Analyzer at heating rate of $5^{\circ} \mathrm{C} / \mathrm{min}$., and $\alpha-\mathrm{Al}_{2} \mathrm{O}_{3}$ was used as a standard reference.

\section{D- Infrared spectra :}

Absorption spectra of natural and prepared clay samples were recorded on FT-IR 27-BRUKER infrared spectrophotometer using $\mathrm{KBr}$ disk, meanwhile, the spectra of the eluted fractions in the study was obtained using $\mathrm{NaCl}$ cell ${ }^{(18)}$.

\section{E- X-Ray Diffraction and Fluorescence :}

$\mathrm{X}$-Ray powder diffraction studies were carried out in Geological Mining State/ Baghdad/ Iraq, using $\mathrm{CuK} \alpha$ radiation, and the diffraction patterns were recorded using Philips/pw/ 1720 powder X-Ray diffractometer filled with a vertical goniometer. The phase contributing to the X-Ray diffraction patterns were identified by reference to the Joint 
Committee on Powder Diffraction Standards powder diffraction file. Meanwhile, X-Ray fluorescence data were obtained from Ministry of science and technology/ Baghdad, using Philips PW 1450/10 Fluorescence Analysis.

\section{F- Application :}

Chromatographic fractionation technique of Qaiyarah heavy crude oil was applied in order to separate such material into its simple components. Three fractionation columns containing clay samples were employed in the processes. These samples were prepared and activated as mentioned previously by heating in an oven at the required temperature.

A known weight (2)g of Qaiyrah petrolene (QP) ${ }^{(10)}$ was fractionated into four fractions using four eluants of different gradually increasing polarities in order to evaluate the adsorption capacities of clay samples.

\section{Results and Discussion :}

\section{A- Solubility in $25 \%$ conc. acids}

It is clear on referring to the previous studies related to the treatment of Iraqi natural mineral clays using basic solutions that such action subjected to the removal of amorphous silica minerals ${ }^{(15)}$. Meanwhile, it seemed that treatment of such materials by different laboratory and industrially available acids specified that each of those acids has its activity and selectivity in removal of one or more of their chemical components. This occur even the fact that those components are physically and chemically bonded together naturally during a very long period. Therefore it is the interest of our research to treat clay materials using $25 \%$ conc. $\mathrm{HCl}, \mathrm{HNO}_{3}, \mathrm{H}_{2} \mathrm{SO}_{4}, \mathrm{H}_{3} \mathrm{PO}_{4}$, and $\mathrm{CH}_{3} \mathrm{COOH}$ progressively. It was noted that the prepared sample losses $59.8 \%$ from its original weight. Data of instrument and classical chemical analysis in addition to that obtained from X-Ray fluorescence, Table (1), clarify the fact that all carbonates and most of sulfate compounds in addition to those compounds which present already in few amounts in the clay sample, were removed. The removal of the above components seemed to enrich the prepared clay sample with clay minerals, which to be discussed later on,since it is so interest in chromatographic adsorption processes.

\section{B- The Study of Physical and Structural Properties :}

Physical properties for both clay samples presented in Table (2). $\mathrm{PH}$ measurement of the prepared sample was acidic in nature compared with that obtained from the natural one. It seems that removing all carbonate and sulphate compounds replaced the alkaline metals by hydrogen ions and leaving the sample containing so many vacancies. 
Bulk density, porosity, and pore size data, Table (2), seemed to point out the characterization of the above pores and cavities which are to be well connected by each others through a very narrow channels. Such observation approved from the determination of capillary action of both samples. Figure(1) show the rapid rise of water in the first few minutes in cases of the prepared sample, which demonstrate the fact that such sample consist of large number of fine cavities well connected by extremely very narrow channels and hence allowing the water to move up easily through the clay sample.

To do our best in investigating the structural properties of our samples we managed by applying powder X-Ray diffraction, thermal analysis and infrared spectroscopy techniques. Figure (2) represents the pattern of natural clay sample which reflect the presence of amorphous silica mineral as a broad hump between $2 \theta(16 \text { and } 28)^{(19)}$. The pattern also contain reflection typical of quartz, feldspar, calcite, dolomite, illite, caolinite, chlorite, and gypsum. Meanwhile, pattern of the prepared sample, Figure (3), reflect the presence of the above minerals in different intensities except calcite and dolomite since they are carbonate compounds and disappeared as a result of the acid effect. Such mixed units of clay minerals are presented in Table (3) via their interplanar spacings ${ }^{(20)}$. Under the proposed experimental observation and referring to the literature ${ }^{(17,19,20)}$, feldsbar mineral seems to be present in acceptable abundance in our sample and classified into three chemical formula:

i- potas group (Orthoclase) and might represented by $\mathrm{KAlSI}_{3} \mathrm{O}_{8}$ has monoclinic symmetry with unit cell values: $\alpha=90^{\circ}, \beta=116.01^{\circ}$ and $\gamma=90^{\circ}$.

ii- Albite $\left(\mathrm{NaAlSI}_{3} \mathrm{O}_{8}\right)$, triclinic, $\alpha=94.16^{\circ}, \beta=116.35^{\circ}$, and $\gamma=87.40^{\circ}$,

iii- Anorthite $\left(\mathrm{CaAl}_{2} \mathrm{SI}_{2} \mathrm{O}_{8}\right)$, triclinic, $\alpha=91.13^{\circ}, \quad \beta=115.51^{\circ}$ and $\gamma=93.10^{\circ}$.

In general all the clay mineral phases held water molecules in their surfaces and bulk pores and cavities and such water molecules might be classified into many kinds according to their departure and removing from the clay sample ${ }^{(4)}$. Therefore DTA were performed for both samples and shown in Figure (4). It seems that endothermic peaks were found corresponding to the two classes of hydrations ; hydroscopic and zeolitic or coordination water molecules. It is clear that some variation is noted in comparison between the observed results before and after the acidic treatment. Such variation might be explained by the fact that treatment by acids might produce so many fractures on the clay surface and hence increasing the bond strength between water molecules and such defect surfaces. To interpret such foundation TG of the prepared sample was preformed and represented in Figure (5). It is clear that losses of 4.3\% and $7.44 \%$ from the original weight were observed and correspond to the above hydration phenomena. 
Finally, it is of insert to investigate the clay mineralogy in addition to the migration and elimination of water molecules by infrared absorption. Therefore, a range of $400-4000 \mathrm{~cm}^{-1}$ in frequency was applied and the spectra revealed structural absorption bands including those between $500-700 \mathrm{~cm}^{-1}$ which are attributed to the $\mathrm{Si}-\mathrm{O}$ stretching and bending vibrations ${ }^{(21)}$. Also there is a band in the rang $3400-3625 \mathrm{~cm}^{-1}$ which is related to the structural $(\mathrm{OH})$ group. Such absorption show a significance variation in the position and sharpness of the vibration upon heating the samples in the range of $120-450^{\circ} \mathrm{C}$ which is related to the dehydration phenomena.

\section{C- Chromatographic Adsorption}

The observed results mentioned above for both clay samples high light, even in different degrees, the fact that such materials are good adsorbents in fractionation processes. They are suitable for the separation of complex mixture into groups of compounds ${ }^{(1-3)}$. As a result, they employed in fractionation of QP into four groups of hydrocarbons. These groups have different adsorption polarities to the clay sample and therefore they were separated by using four eluants increased gradually in their polarities. Table (4) revealed the percentages of the fractions eluted on packing three columns with chromatographic grade (120 - 150 mesh) natural, activated $450^{\circ} \mathrm{C}$, and the prepared clay samples. In general the observed results show a notable variation between the separated groups, but there is no doubt that adsorption and desorption processes of QP was occurred and in high degrees of activity and selectivity. Data of the prepared sample seemed to be better than others but indeed such fact has to be conformed by studying the chemical characteristic nature of the eluted fractions. It was adopted from the previous studies ${ }^{(10,7)}$ and relaying on their infrared data which are presented in Table (5). It is obvious that the results reflect the fact that all the eluted fractions contain straight aliphatic hydrocarbons via the adsorption bands at 2925 and 1461 $\mathrm{cm}^{-1}$ which are attributed to the stretching and bending vibrations of methylene groups. Interference of branched aliphatic, naphthenic and aromatic compounds was happened and represented in the table by absorption bands at 2825, $1377 \mathrm{~cm}^{-1}, 2842 \mathrm{~cm}^{-1}$ and $1604 \mathrm{~cm}^{-1}$ which are related to $\mathrm{CH}_{3}$, naphthenic $-\mathrm{CH}_{2}$ and aromatic $(\mathrm{C}-\mathrm{C})$ groups respectively ${ }^{(22)}$.

It is of importance to report that infrared technique is not enough to reach the goal of the present study. However, on comparison between the shown data through their positions and intensities, it seems that first fraction contains mainly of straight aliphatics, while the second is branched aliphatics, the third is nahpthenics and finally the forth eluted fraction is riched with aromatic hydrocarbons. Interference between the 
above groups in fact was occurred but in conclusion the results suggest that the whole interference was low in using the prepared clay sample which is assumed to be an activated adsorption catalyst and has a promising future.

\section{References :}

1) H. Rethel and K.E. Stanfield, Anal. Chem., 20, 460, (1948).

2) M. William, Anal Chem., 39, 14, (1967).

3) C. Liu, G Qne, y. Ohen, and L. Liang, Fuel Sci. Tech. Int., 1, 449, (1988).

4) M. Ozacar, A. Alpand, and A. Aydin, J. Thermal anal. color., 59(3), 869, (2000).

5) P. Thune and R. Linke, J. Phys. Chem., B.,105(15), 3073, (2001).

6) E.Akawwi and A. Al - Karabsheh, lime stabilization effect on geotechnical properties of expensive soils in Amman Jordan, (internet), (2002).

7) R. A. Buker and S. A. Al-Mallah, J. Edu. Sci.,17 (4), 42,(2005).

8) B.P. Statistical, Review of World Energy, (1980).

9) L. H. Ali, K. A. Al- Ghanam, and J. M. Al - Rawi, Fuel, 69, 519, (1990).

10) O. M. Ramadan and R. A. Buker, Fuel Sci. Tech. Int. 11, 7, (1992).

11) R. A. Buker and L. Mubarak, J. Rafidaine Sci., 13, 11, (2001).

12) O. M. Ramadhan and R. Y. Ghazl, National J. Chem., 16, 11, (2004).

13) A. S. Al-Juboury, M. Sc. Thesis, College of Science, University of Mosul, (1999).

14) R. A. Buker and F. R. Kadir, National J. Chem., 7, March, (2005).

15) S. A. Al- Mallah, M.Sc. Thesis, College of Education University of Mosul, (2005).

16) P. G. Jeffery and D. Hutchison, "Chemical Methods of Analysis", $3^{\text {rd }}$ ed., Pergamon Press, (1981).

17) R. Jenkins and J. L. D. Vries, "Practical X-Ray Spectroscopy", Hazel Watson and Viney ltd., London, (1975).

18) K. Nakamoto, "IR and Ramman Spectra of Inorganic Compounds", $5^{\text {th }}$ Ed., John and Willy Sons., New York, (1997).

19) K. Cornelis, "Mineral Science", $22^{\text {nd }}$ ed., John Wiley and Sons, New York, (2003).

20) N. Johnson, "X-Ray Diffraction for Geological Applications", Schimadzu Group Company, (2000).

21) D. Barthemy, "Mineralogy Database Plagioclase Feldspar Series", Hershel Friedman (2003).

22) R. Silverstien G. C. Bassler and T. C. Morrell, "Spectrometric Identification of Organic Compounds", $4^{\text {th }}$ ed. John Wiley and Sons., New York, (1980). 
Local Mineral Clays, Characterization and Application in Petroleum Refining.

Table (1): Average data analysis of clay samples.

\begin{tabular}{|c||c|c|c|c|c|c|c|c|c|}
\hline Sample & Oxides & $\mathrm{Na}_{2} \mathrm{O}$ & $\mathrm{K}_{2} \mathrm{O}$ & $\mathrm{CaO}$ & $\mathrm{MgO}$ & $\mathrm{Al}_{2} \mathrm{O}_{3}$ & $\mathrm{Fe}_{2} \mathrm{O}_{3}$ & $\mathrm{SO}_{3}$ & $\mathrm{SiO}_{3}$ \\
\hline \hline \multirow{2}{*}{ Natural } & $\begin{array}{c}\text { Wet } \\
\text { analysis }\end{array}$ & $\mathbf{0 . 3 3}$ & $\mathbf{5 . 7 0}$ & $\mathbf{1 4 . 7 0}$ & 1.90 & 7.3 & $\mathbf{2 8 . 0 0}$ & $\mathbf{2 . 3 0}$ & $\mathbf{3 6 . 4 1}$ \\
& XRF & $\mathbf{0 . 3 1}$ & $\mathbf{4 . 4 9}$ & $\mathbf{1 2 . 2 8}$ & $\mathbf{1 . 3 9}$ & $\mathbf{4 . 4 6}$ & $\mathbf{3 8 . 1 2}$ & $\mathbf{2 . 1 9}$ & $\mathbf{3 5 . 3 0}$ \\
\hline \multirow{2}{*}{ Prepared } & $\begin{array}{c}\text { Wet } \\
\text { analysis }\end{array}$ & $\mathbf{0 . 7 1}$ & $\mathbf{6 . 8 0}$ & $\mathbf{0 . 1 8}$ & $\mathbf{0 . 0 1}$ & $\mathbf{1 0 . 3 0}$ & $\mathbf{3 5 . 4 0}$ & $\mathbf{0 . 0 1}$ & $\mathbf{4 5 . 0 0}$ \\
\cline { 2 - 9 } & XRF & $\mathbf{0 . 3 3}$ & $\mathbf{8 . 0 3}$ & $\mathbf{1 . 2 0}$ & $\mathbf{0 . 1 3}$ & $\mathbf{4 . 9 5}$ & $\mathbf{4 0 . 8 2}$ & $\mathbf{0 . 4 3}$ & $\mathbf{4 4 . 1 1}$ \\
\hline
\end{tabular}

Table(2): Physical properties of clay samples.

\begin{tabular}{|c|c|c|c|c|c|c|}
\hline Sample & $\begin{array}{l}\text { Density } \\
\text { gm/cm }\end{array}$ & $\begin{array}{c}\text { Porosity } \\
\%\end{array}$ & $\begin{array}{c}\text { Surface area } \\
\mathrm{gm} / \mathrm{cm}^{3}\end{array}$ & $\begin{array}{c}\text { Pore size } \\
\mathrm{cm}^{3} / \mathrm{mg}\end{array}$ & $\begin{array}{c}\text { Water } \\
\text { absorption \% }\end{array}$ & PH \\
\hline Natural & 2.99 & 231.25 & 200.12 & 5.36 & 97.98 & 8.01 \\
\hline Prepared & 2.03 & 255.82 & 257.37 & 6.01 & 147.53 & 3.99 \\
\hline
\end{tabular}

Table(3): Interplanar spacing for contributing phases in clay sample.

\begin{tabular}{|c|c|c|c|}
\hline Crystalline phases & hkl & $2 \theta$ & ${\text { d values } A^{\circ}}^{\circ}$ \\
\hline kaolinite & 001 & 12.4 & 7.165 \\
\hline chlorite & 002 & 12.4 & 7.150 \\
\hline Ab/ Feldsbar & $\mathbf{0 2 0}$ & 13.8 & 6.443 \\
\hline kaolinite & 021 & 19.9 & 4.460 \\
\hline Quartz & 100 & 20.9 & 4.248 \\
\hline Gypsum & 021 & 20.8 & 4.248 \\
\hline Ab/ Feldsbar & 201 & 22.2 & 4.015 \\
\hline calcite & 102 & 23.0 & 3.869 \\
\hline Illite & 113 & 24.2 & 3.685 \\
\hline Or /Feldsbar & 220 & 26.6 & 3.350 \\
\hline Quartz & 101 & 26.6 & 3.343 \\
\hline An/ Feldsbar & 204 & 27.9 & 3.203 \\
\hline calcite & 104 & 29.4 & 3.036 \\
\hline Dolomite & 104 & 31.0 & 2.887 \\
\hline Gypsum & 200 & 31.0 & 2.887 \\
\hline Or /Feldsbar & 132 & 32.4 & 2.766 \\
\hline Illite & 116 & 34.9 & 2.583 \\
\hline Chlorite & 203 & 36.1 & 2.491 \\
\hline Gypsum & 202 & 36.9 & 2.436 \\
\hline Kaolinite & 003 & 37.7 & 2.383 \\
\hline calcite & 113 & 39.5 & 2.280 \\
\hline Or /Feldsbar & 003 & 42.5 & 2.127 \\
\hline calcite & 202 & 43.3 & 2.087 \\
\hline Kaolinite & 132 & 45.6 & 1.990 \\
\hline calcite & 018 & 47.6 & 1.911 \\
\hline calcite & 116 & 48.7 & 1.870 \\
\hline Dolomite & 018 & 50.2 & 1.818 \\
\hline Illite & 311 & 53.9 & 1.699 \\
\hline Kaolinite & 133 & 54.9 & 1.671 \\
\hline Dolomite & 211 & 57.6 & 1.599 \\
\hline Chlorite & 208 & 57.6 & 1.599 \\
\hline Chlorite & 060 & 59.9 & 1.549 \\
\hline
\end{tabular}


R. A. Buker \& M. Z. Hamoodat

Table(4): Percentage fraction of $Q P *$ on using clay sample.

\begin{tabular}{|c||c|c|c|c|}
\hline Solvent & Polarity(deby) & Natural & Natural 450 ${ }^{\circ} \mathrm{C}$ & Prepared \\
\hline \hline n- Hexane & 31.0 & 58.5 & 56.5 & 45.0 \\
\hline Toluene & 33.9 & 15.0 & 16.5 & 21.5 \\
\hline $\begin{array}{c}\text { Dichloro } \\
\text { methylene }\end{array}$ & 39.1 & 11.0 & 15.5 & 15.0 \\
\cline { 1 - 4 } Ethanol & $\mathbf{5 1 . 9}$ & 12.5 & 9.5 & 15.5 \\
\hline Loss & & 3.0 & 2.0 & 3.0 \\
\hline
\end{tabular}

QP* composition: straight aliphatic $38 \%$ branched aliphatic $27 \%$ naphthenic $18 \%$ and aromatic Compounds $17 \%{ }^{(10)}$.

Table (5): Infrared adsorption bands for aliphatic, naphthenic and aromatic hydrocarbons eluted on using clay sample.

\begin{tabular}{|c|c|c|c|c|c|c|}
\hline \multirow[b]{2}{*}{ Sample } & \multirow[b]{2}{*}{ Solvent } & \multicolumn{2}{|c|}{ Aliphatic } & \multirow{2}{*}{$\begin{array}{l}\text { Naphthenic } \\
(\mathrm{C}-\mathrm{H}) \mathrm{CH}_{2}\end{array}$} & \multicolumn{2}{|c|}{ Aromatic } \\
\hline & & $\begin{array}{c}\mathrm{C}-\mathrm{H}) \\
\mathrm{CH}_{3} \\
\end{array}$ & $\begin{array}{c}(\mathrm{C}-\mathrm{H}) \\
\mathrm{CH}_{2} \\
\end{array}$ & & (C-H) & $\mathrm{C}=\mathrm{C}$ \\
\hline \multirow{4}{*}{$\begin{array}{l}\text { Natural } \\
\text { clay }\end{array}$} & Hexane & $\begin{array}{l}\text { 2955(s) } \\
1377(\mathrm{~m})\end{array}$ & $\begin{array}{l}\text { 2925(s) } \\
1461(s)\end{array}$ & $\begin{array}{l}2854(s) \\
1461(s)\end{array}$ & $\begin{array}{c}\text { 3080(w),1034(w) } \\
875(w), 814(w)\end{array}$ & $1603(\mathrm{vw})$ \\
\hline & Toluene & $\begin{array}{c}2955(\mathrm{~s}) \\
1377(\mathrm{~m})\end{array}$ & $\begin{array}{l}2923(s) \\
1485(s)\end{array}$ & $\begin{array}{c}2855(\mathrm{~m}) \\
1458(\mathrm{~s})\end{array}$ & $\begin{array}{c}\text { 3087(vw),1032(w) } \\
864(w)\end{array}$ & $1601(w)$ \\
\hline & $\begin{array}{l}\text { Dichloro } \\
\text { methylene }\end{array}$ & $\begin{array}{l}\text { 2953(m) } \\
\text { 1379(m) }\end{array}$ & $\begin{array}{l}2926(s) \\
1462(s)\end{array}$ & $\begin{array}{l}2856(s) \\
1462(s)\end{array}$ & $\begin{array}{c}3080(\mathbf{w}) \\
1039(\mathbf{s})\end{array}$ & $1600(w)$ \\
\hline & Ethanol & $\begin{array}{l}\text { 2951(s) } \\
1380(\mathrm{~m})\end{array}$ & $\begin{array}{l}\text { 2927(s) } \\
1462(s)\end{array}$ & $\begin{array}{l}\text { 2858(s) } \\
1462(s)\end{array}$ & $\begin{array}{c}3080(w), 1072(s) \\
1040(s)\end{array}$ & $1600(\mathrm{~m})$ \\
\hline \multirow{4}{*}{$\begin{array}{l}\text { Natural } \\
\text { clay } \\
450^{\circ} \mathrm{C}\end{array}$} & Hexane & $\begin{array}{l}\text { 2954(m) } \\
1377(\mathrm{~s})\end{array}$ & $\begin{array}{l}2931(\mathrm{~m}) \\
1462(\mathrm{~s})\end{array}$ & $\begin{array}{l}2844(s) \\
1462(s)\end{array}$ & $\begin{array}{c}\text { 3080(w),1034(w) } \\
805(s)\end{array}$ & $1604(\mathrm{vw})$ \\
\hline & Toluene & $\begin{array}{l}\text { 2953(s) } \\
1378(\mathrm{~m})\end{array}$ & $\begin{array}{l}2926(\mathrm{~s}) \\
1460(\mathrm{~m})\end{array}$ & $\begin{array}{l}2856(\mathrm{~s}) \\
1460(\mathrm{~m})\end{array}$ & $3060(v w)$ & $1604(w)$ \\
\hline & $\begin{array}{c}\text { Dichloro } \\
\text { methylene }\end{array}$ & $\begin{array}{l}\text { 2956(m) } \\
1378(w)\end{array}$ & $\begin{array}{l}2927(m) \\
1462(w)\end{array}$ & $\begin{array}{l}2855(m) \\
1462(w)\end{array}$ & $\begin{array}{c}3080(w), 1005(\mathrm{~m}) \\
808(\mathrm{~s})\end{array}$ & $1605(\mathrm{~m})$ \\
\hline & Ethanol & $\begin{array}{l}2956(w) \\
1377(w)\end{array}$ & $\begin{array}{c}2927(w) \\
1459(v w)\end{array}$ & $\begin{array}{c}2856(w) \\
1459(v w)\end{array}$ & $\begin{array}{c}\text { 3080(m) } \\
907(\mathrm{~s})\end{array}$ & $1607(s)$ \\
\hline \multirow{4}{*}{$\begin{array}{l}\text { Prepared } \\
\text { clay }\end{array}$} & Hexan & $\begin{array}{l}2953(\mathrm{~m}) \\
1379(\mathrm{~m})\end{array}$ & $\begin{array}{l}2927(s) \\
1463(s)\end{array}$ & $\begin{array}{l}2856(s) \\
1463(s)\end{array}$ & $\begin{array}{c}3067(v w) \\
1036(v w) \\
875(w), 813(w) \\
\end{array}$ & $1604(\mathrm{vw})$ \\
\hline & Toluene & $\begin{array}{l}\text { 2955(s) } \\
\text { 1377(s) }\end{array}$ & $\begin{array}{l}\text { 2925(s) } \\
1459(s)\end{array}$ & $\begin{array}{l}2855(s) \\
1459(s)\end{array}$ & $\begin{array}{c}3067(\mathrm{vw}) \\
1033(\mathrm{vw}) \\
864(\mathrm{w}) \\
\end{array}$ & $1600(\mathrm{vw})$ \\
\hline & $\begin{array}{l}\text { Dichloro } \\
\text { methanol }\end{array}$ & $\begin{array}{l}2955(w) \\
1377(w)\end{array}$ & $\begin{array}{l}2924(w) \\
1458(w)\end{array}$ & $\begin{array}{l}2855(v w) \\
1458(w)\end{array}$ & $\begin{array}{c}3080(w) \\
1004(s) \\
883(s)\end{array}$ & $1653(w)$ \\
\hline & Ethanol & $\begin{array}{l}2955(v w) \\
1377(v w) \\
\end{array}$ & 2927(vw) & $2855(v w)$ & $\begin{array}{c}3080(\mathrm{~m}) \\
1007(\mathrm{~s})\end{array}$ & 1634(s) \\
\hline
\end{tabular}

s: strong, m: medium, w: weak, vw: very weak. 


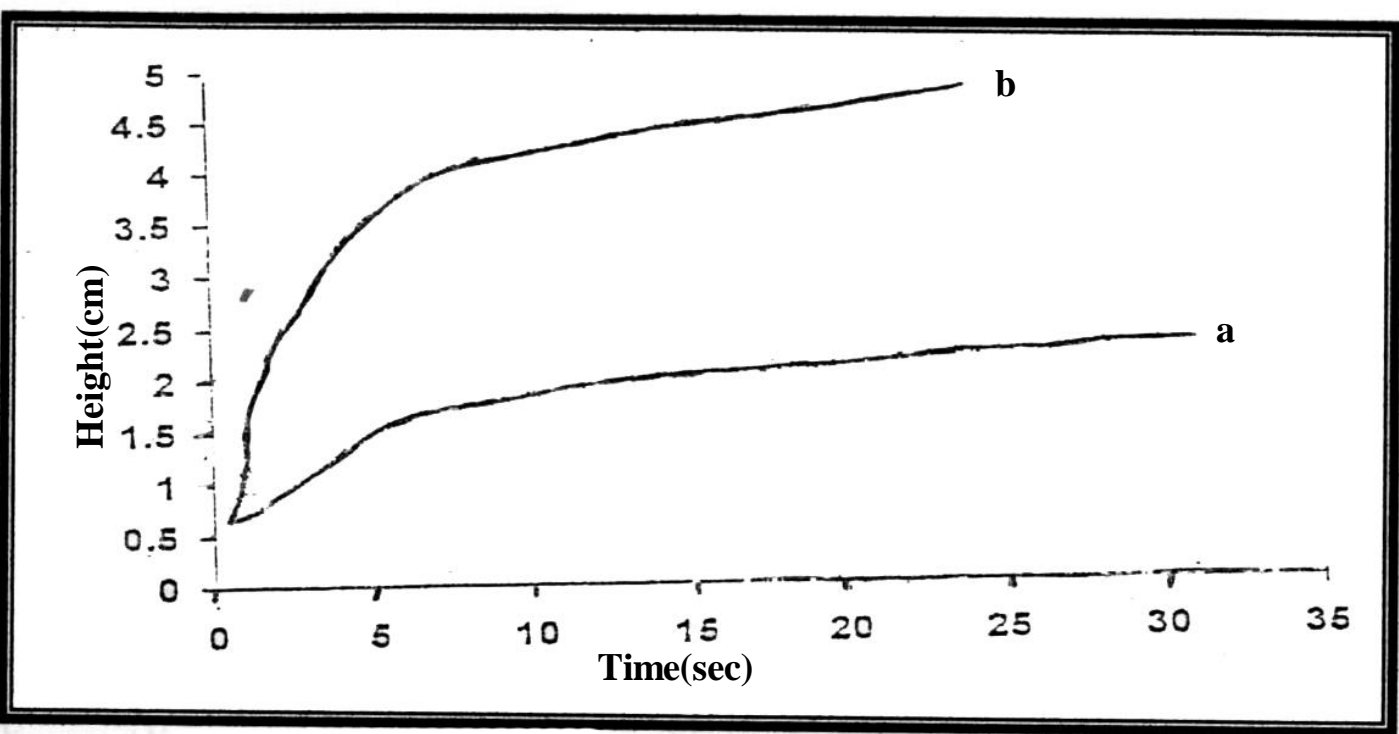

Figure(1): Capillary action curves of (a) Natural and (b) Prepared clay samples.

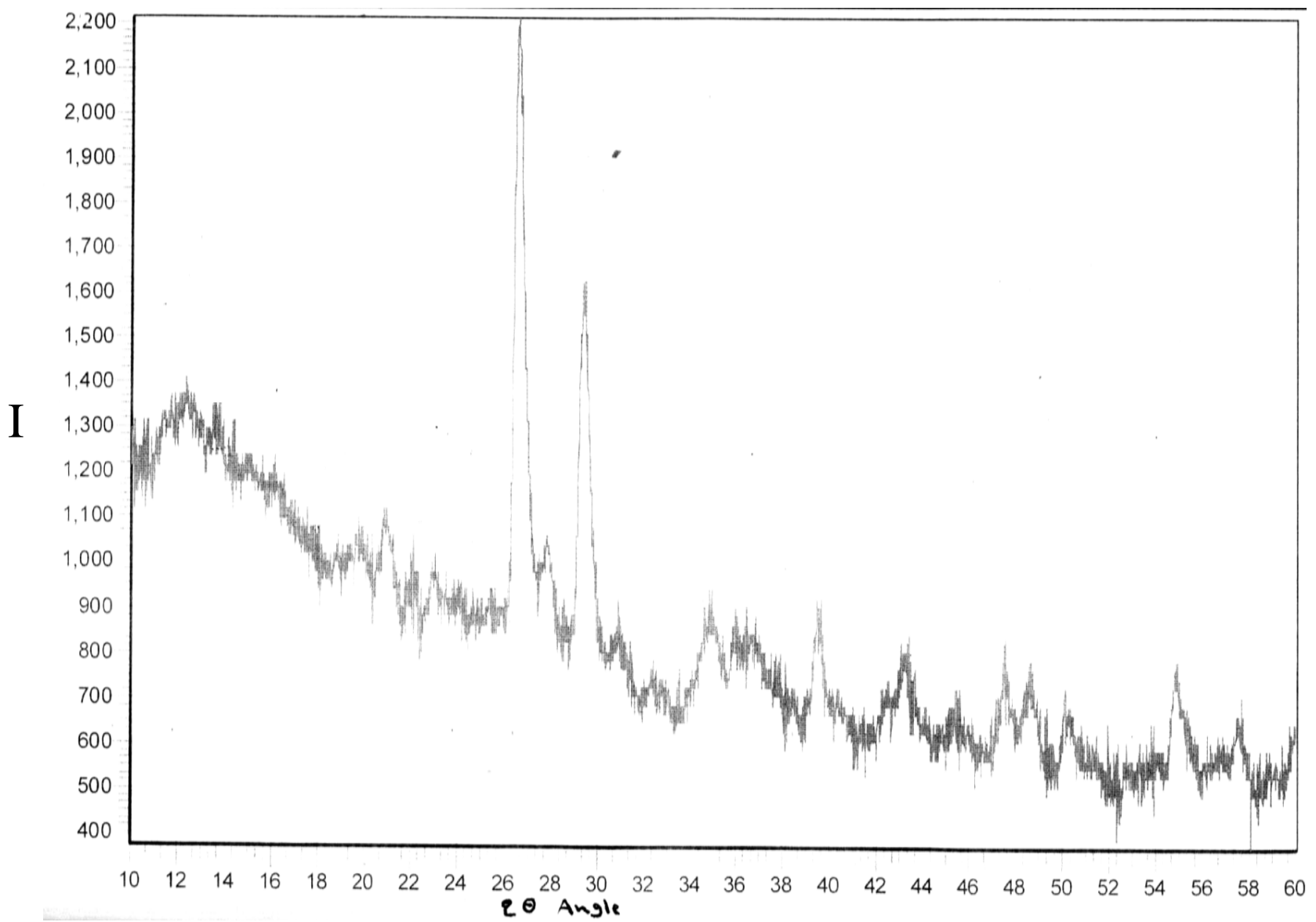

Figure(2): Powder X-Ray diffraction Pattern of natural clay sample. 
R. A. Buker \& M. Z. Hamoodat

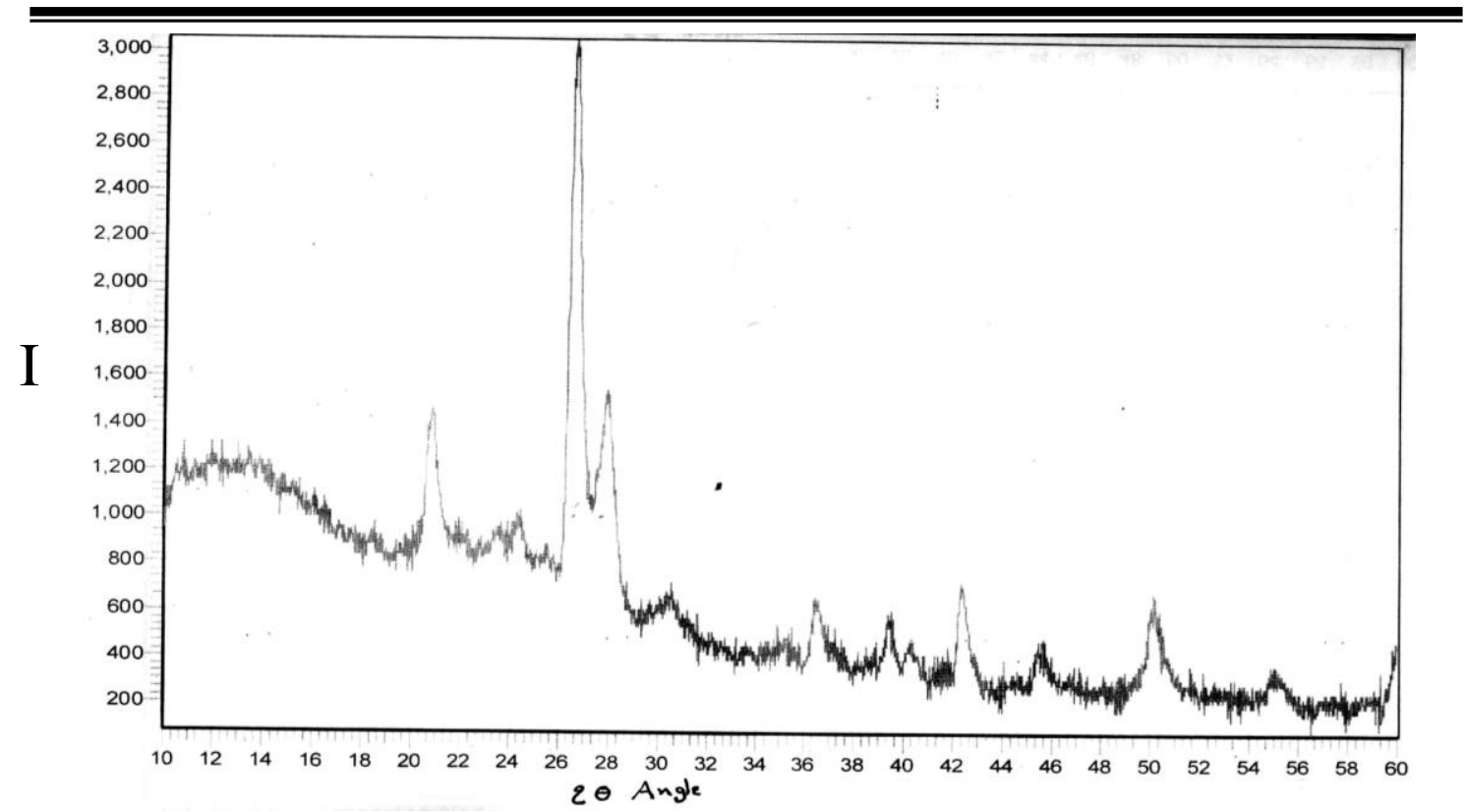

Figure(3): Powder X-Ray diffraction Pattern of the prepared clay sample.

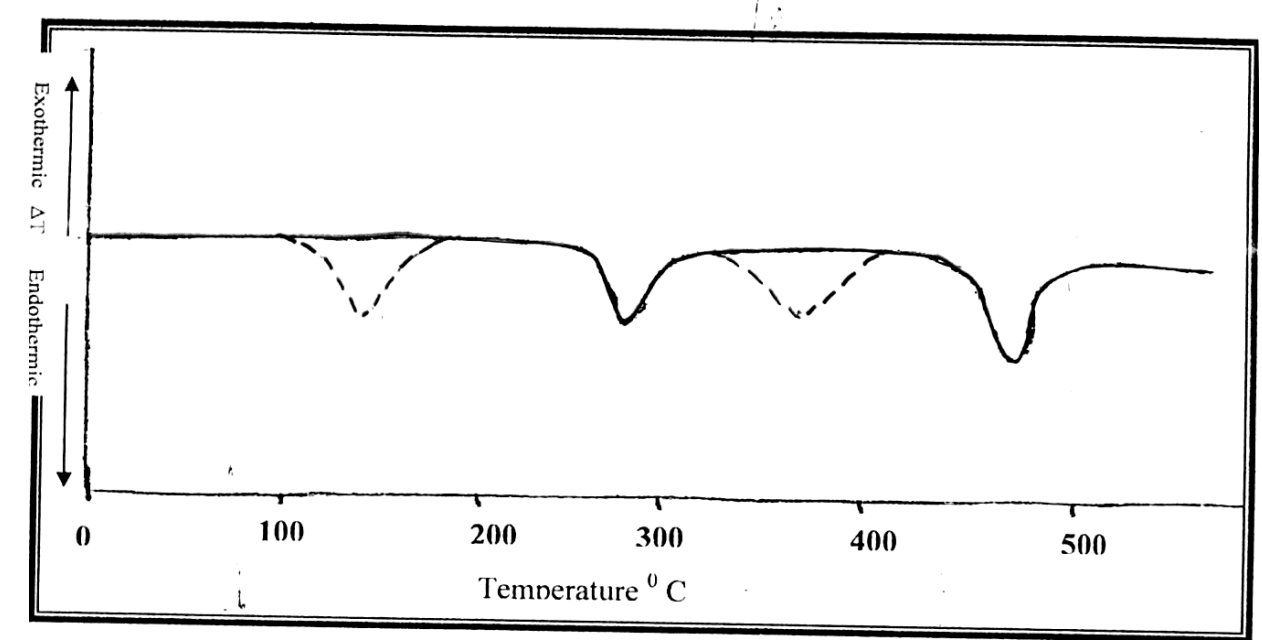

Figure(4): DTA curves of natural clay (......) and prepared sample(-).

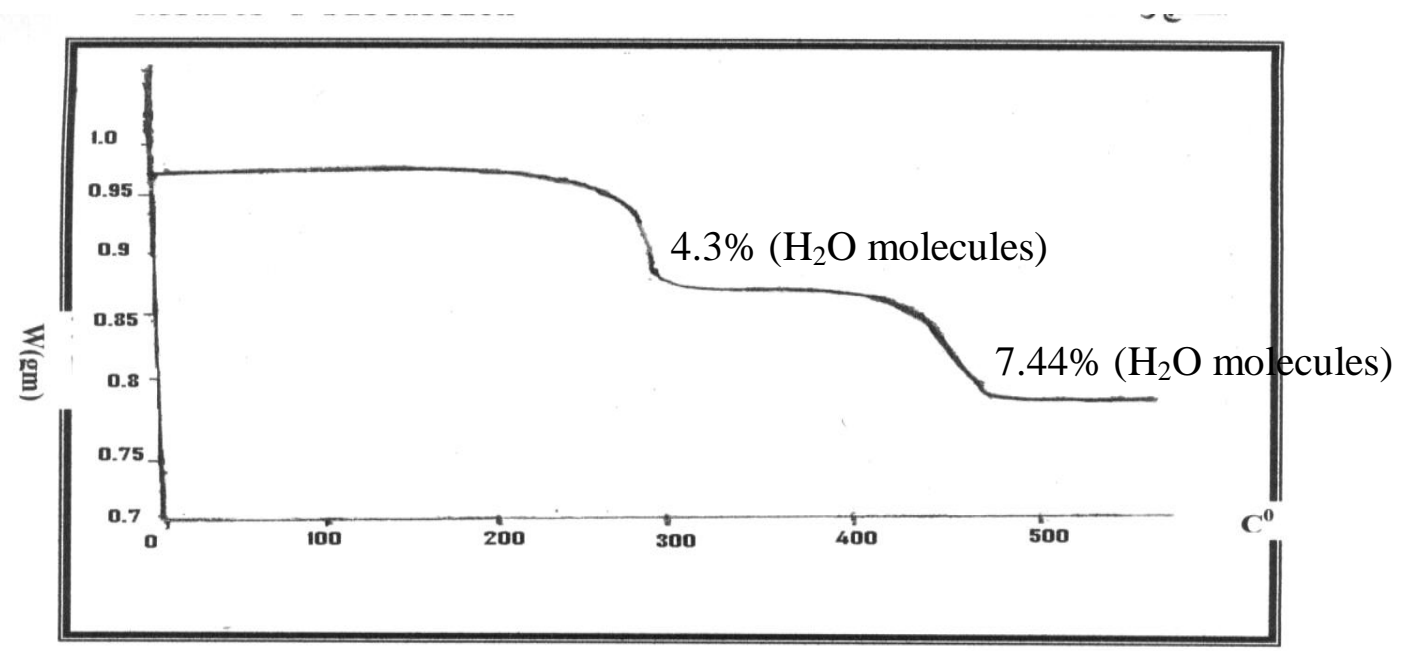

Figure(5): TG curve of the prepared clay sample. 